\title{
Comparison of Retrograde Intrarenal Surgery and Micro-percutaneous Nephrolithotomy for Kidney Stones 5-10 mm in Diameter
}

\section{5-10 mm Böbrek Taşlarında Retrograde Intrarenal Cerrahi ile Mikroperkütan Nefrolitotomi Sonuçlarının Kıyaslanması}

๑ Bayram Güner, ๑ Bilal Günaydın*

Edremit Körfez Hospital, Clinic of Urology, Balıkesir, Turkey

*Ömer Halisdemir University Faculty of Medicine, Department of Urology, Niğde, Turkey

Abstract

Aim: To compare the results of micro-percutaneous nephrolithotomy (micro-PNL) and retrograde intrarenal surgery (RIRS) for symptomatic renal stones 5-10 $\mathrm{mm}$ in diameter.

Methods: A total of 86 patients, who underwent RIRS ( $n=53)$ and micro-PNL $(n=23)$, were evaluated retrospectively. Urine analysis, serum creatinine level, urine culture and non-contrast computed tomography scan were performed in all patients preoperatively. Kidney stones were opaque in all cases. Unresolved coagulopathy, active urinary infection, morbid obesity, missing data and pregnancy were considered the criteria for exclusion. The groups were compared in terms of operative time, Visual analogue scale score, analgesic requirement, retreatment, transition to other treatment, complication and stone-free rates and length of hospital stay.

Results: Both surgical techniques were similar for all parameters except need for analgesics, which was higher in the micro-PNL group ( $p=0.026$ ). The stone-free rate was $85.7 \%$ in the RIRS group and $78.2 \%$ in the micro-PNL group ( $p=0.43$ ).

Conclusion: Both methods can be administered as alternative modalities with high success and low complication rates. However, analgesics requirement was higher in micro-PNL group.

Keywords: Micro-percutaneous nephrolithotomy, retrograde intrarenal surgery, kidney stone, ureteroscopy
Öz

Amaç: 5-10 mm böbrek taşına sahip hastalarda retrograd intrarenal cerrahi (RIRC) ve mikroperkütan nefrolitotomi (mikroPNL) operasyonlarının sonuçlarını karşılaştırmak amaçlandı.

Yöntemler: RIRC ve mikro-PNL yapılan hastaların kayıtları hastane dijital veri tabanı ve servis dosyalarından tarandı ve bunlar içerisinden opak taşa sahip 53'ü RIRC olmak üzere toplam 86 hasta çalışmaya dahil edildi. Düzeltilemeyen koagülopatiye, aktif üriner enfeksiyona, morbid obeziteye, eksik veriye ve opak olmayan taşa sahip hastalar çalışmadan dışlandı. Operasyon Öncesi tüm hastalara tam idrar tetkiki, kreatinin, idrar kültürü, kontrastsız bilgisayarlı tomografi yapıldı. Gruplar demografik veriler, taş karakteristikleri, operasyon süresi, Görsel Ağrı skoru, ağrı kesici ihtiyacı, yeniden tedavi ve diğer tedaviye geçiş oranları, komplikasyon oranları, hastanede kalış süresi ve başarı açılarından karşılaştıııldı.

Bulgular: Ağrı kesici ihtiyacı mikro-PNL grubunda daha yüksek bulundu $(p=0,026)$. Bakılan diğer parametreler her iki grupta benzer idi. Taşsızlık oranı RIRC grubunda \%85,7; mikro-PNL grubunda $\% 78,2$ idi $(p=0,43)$.

Sonuç: RIRC ve Mikro-PNL, 5-10 mm arası böbrek taşlarında benzer başarı oranlarına sahip olmasına karşın analjezik ihtiyacı açısından RIRC daha avantajlıdır.

Anahtar Sözcükler: Mikroperkütan nefrolitotomi, retrograd intrarenal cerrahi, böbrek taşı, üreteroskopi
Address for Correspondence/Yazışma Adresi: Bayram Güner, Edremit Körfez Hospital,

Clinic of Urology, Balıkesir, Turkey

E-mail: gunerbayram@yahoo.com ORCID: orcid.org/0000-0001-7602-2255

Received/Geliş Tarihi: 05 September 2019 Accepted/Kabul Tarihi: 22 January 2020

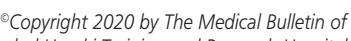
istanbul Haseki Training and Research Hospital The Medical Bulletin of Haseki published by Galenos Yayınevi. ${ }^{\circ}$ Telif Hakkı 2020 İstanbul Haseki Eğitim ve Araştırma Hastanesi Haseki Tıp Bülteni, Galenos Yayınevi tarafindan yayınlanmıştı. 


\section{Introduction}

Minimally-invasive treatment options are one of the most important determinants of current practice in patients with urinary stone disease. Owing to technological improvements, there are extremely rapid developments especially in the treatment of kidney stones. In addition to advances in extracorporeal shock wave lithotripsy (SWL), advances in retrograde intrarenal surgery (RIRS) and miniaturized percutaneous nephrolithotomy (mini-PNL) have reduced the use of open surgery.

The European Association of Urology urolithiasis guideline recommends standard PNL as the first choice in the treatment of kidney stones larger than $2 \mathrm{~cm}(1)$. Although PNL is accepted as a safe method, it can lead to life-threatening hemorrhages. Considering that hemorrhage in standard PNL is directly related to the instruments used, the diameters of the instruments have been reduced over the years. In the following years, developments have continued with defining smaller diameter systems such as ultra-m-PNL, super mini-PNL and micro-PNL techniques (25). Flexible ureteroscopy has superiorities such as the use of natural orifices, short-stay hospitalization, the advantage of concurrent access to all locations of the renal calyceal system, avoidance of complications resulting from dilatation and adjacent organ injuries in percutaneous interventions, low morbidity, and stone-free rates similar to that with percutaneous interventions. Micro-PNL does not need dilatation and especially, the risk of hemorrhage is lower than in standard PNL. Although there is no consensus on the optimal treatment for 5-20 mm kidney stones. SWL, RIRS and PNL (ultra mini-PNL, super mini-PNL and micro-PNL) alternatives can be used. In this study, we aimed to compare the results of RIRS and micro-PNL performed in symptomatic kidney stones 5 to $10 \mathrm{~mm}$ in size.

\section{Methods}

A total of 86 patients (14 females, 72 males), who were admitted to our center with renal stones smaller than $1 \mathrm{~cm}$ between June 2013 and November 2018 were included in the study. Patients who underwent micro-PNL were defined as group 1 and patients who underwent RIRS were defined as group 2. A complete urinalysis, serum creatinine measurement, urine culture and non-contrast computed tomography scan was performed in each patient. All patients had opaque stone. The procedure was performed by a single surgeon. Unresolved coagulopathy, active urinary infection, morbid obesity, having missing data and pregnancy were considered as the exclusion criteria.

\section{Micro-percutaneous Nephrolithotomy}

Following insertion of a 3-5F open-ended ureteral catheter in the lithotomy position under spinal anesthesia,
micro-PNL procedure was performed via direct access to the stone or, in necessary cases, through retrograde pyelography with the help of a $4.85 \mathrm{~F}$ all-seeing needle in the prone position. The procedure was performed by a single surgeon.

\section{Retrograde Intrarenal Surgery}

Flexible ureteroscopy (Karl Storz Flex X2, Stuttgart) was performed routinely under spinal anesthesia in all cases except for two patients. A guidewire was placed in the renal pelvis through a semirigid ureteroscope. The procedure was performed without using a ureteral access sheath in most cases. In only three patients, a 9.5/11F ureteral access sheath was used because of cost effectiveness and risk of ureteral trauma. A 270-micron laser fiber was used for fragmentation (1-1.5 Joule, $5-10 \mathrm{~Hz}$ ) (Dornier Medilas $\mathrm{H}$ Solvo 30W). At the end of fragmentation, a $4.8 \mathrm{~F} 26 \mathrm{~cm} \mathrm{~J}$ stent was inserted in all patients via a semirigid ureteroscope and was removed on the $14^{\text {th }}$ day postoperatively. The procedure was performed by a single surgeon.

Extracorporeal shock wave therapy was not performed before the procedures. All the patients, who underwent micro-PNL, were discharged on the postoperative day 1 and ureteral and Foley catheters were removed. All patients were followed up at $10^{\text {th }}$ day and every 3 months postoperatively. None of the patients received medical therapy other than analgesic and antispasmodic treatment. Oral quinolone was given for three days postoperatively. Stone free rates were demonstrated by the absence of residual fragment on the combination of X-ray and ultrasonography two weeks postoperatively. Complications were evaluated according to the Modified Clavien Classification System (1).

\section{Statistical Analysis}

Data were analyzed by using the Statistical Package for the Social Sciences version 20 (SPSS Inc., Chicago, IL, USA). Quantitative data were expressed as mean \pm standard deviation on tables and categorical data were expressed with frequency ( $n$ ) and percentages (\%). The distribution of the variables was measured by the Kolmogorov-Smirnov test. The independent samples t-test was used to compare independent groups. Pearson's correlation coefficient was used to examine the relationship between variables. Pearson's chi-squared and Fisher's exact tests were used to compare the categorical data. The data were analyzed at 95\% confidence level and the threshold for statistical significance was accepted as $p<0.05$ for all analysis.

\section{Results}

One patient in micro-PNL group needed I stent placement on the $3^{\text {rd }}$ postoperative day because of 
pain and hydronephrosis. Fever occurred in only one patient in micro-PNL group. In RIRS group, three patients required ureteral access sheath and one patient required retreatment for the stone. In RIRS group, complete fragmentation could not be achieved due to bleeding in two patients and stone free status was achieved with SWL. Flexible ureteroscopy was not performed in these patients because the visualization would be poor due to bleeding. In micro-PNL group, two patients underwent flexible ureteroscopy due to problems in stone fragmentation. In three patients in RIRS group, the operation was converted to micro-PNL because the kidney could not be accessed due to ureteral stenosis. No hemoglobin decrease occurred in any of the patients. The demographic data and stone characteristics are given in Table 1. There was no statistically significant difference between the groups in terms of intra- and postoperative parameters except for analgesic requirement (Table 2).

\section{Discussion}

The main treatment modalities used in the surgical treatment of kidney stones consist of retrograde endoscopic procedures performed using natural orifices and the procedures that provide percutaneous access in various diameters and sizes (1). In both techniques, advances in miniaturization, high image quality and irrigation advantage have enriched the treatment alternatives. Currently, urologists are more familiar with retrograde procedures. Rapidly expanding ureteroscopy procedures have led us to gain an alternative procedure in kidney stones especially smaller than $2 \mathrm{~cm}$ with a high success rate versus percutaneous interventions. There is

\begin{tabular}{|c|c|c|c|c|}
\hline \multicolumn{2}{|l|}{ Parameters } & $\begin{array}{l}\text { Micro-PNL } \\
(\mathrm{n}=23)\end{array}$ & $\begin{array}{l}\text { RIRS } \\
(n=63)\end{array}$ & p \\
\hline \multicolumn{2}{|l|}{ Age } & $53.04 \pm 11.25$ & $51.94 \pm 10.41$ & 0.67 \\
\hline \multicolumn{2}{|c|}{ Stone diameter } & $8.91 \pm 1.12$ & $8.06 \pm 1.51$ & $0.018^{*}$ \\
\hline Laterality & $\begin{array}{l}\text { Right } \\
\text { Left }\end{array}$ & $\begin{array}{l}17(73.9 \%) \\
6(26.1 \%)\end{array}$ & $\begin{array}{l}26(41.3 \%) \\
37(58.7 \%)\end{array}$ & $0.007^{*}$ \\
\hline $\begin{array}{l}\text { Number of } \\
\text { stone }\end{array}$ & $\begin{array}{l}\text { Single } \\
\text { Multiple }\end{array}$ & $\begin{array}{l}21(91.3 \%) \\
2(8.7 \%)\end{array}$ & $\begin{array}{l}59(93.7 \%) \\
4(6.3 \%)\end{array}$ & 0.70 \\
\hline Localization & $\begin{array}{l}\text { Upper pole } \\
\text { Middle pole } \\
\text { Lower pole } \\
\text { Pelvis }\end{array}$ & $\begin{array}{l}0 \\
7(30.4 \%) \\
11(47.8 \%) \\
5(21.7 \%)\end{array}$ & $\begin{array}{l}3(4.8 \%) \\
15(23.8 \%) \\
34(54 \%) \\
11(17.5 \%)\end{array}$ & 0.64 \\
\hline Comorbidity & $\begin{array}{l}+ \\
- \\
\text { DM } \\
\mathrm{Ht} \\
\text { CVD } \\
\text { CAD }\end{array}$ & $\begin{array}{l}6(26.1 \%) \\
17(73.9 \%) \\
4(17.4 \%) \\
1(4.3 \%) \\
0 \\
1(4.3 \%)\end{array}$ & $\begin{array}{l}23(36.5 \%) \\
40(63.5 \%) \\
10(15.9 \%) \\
6(9.5 \%) \\
3(4.8 \%) \\
4(6.3 \%)\end{array}$ & $\begin{array}{l}0.36 \\
- \\
0.92 \\
0.39 \\
0.26 \\
0.64\end{array}$ \\
\hline \multicolumn{5}{|c|}{$\begin{array}{l}\text { PNL: Percutaneous nephrolithotomy, RIRS: Retrograde intrarenal surgery } \\
\text { DM: Diabetes Mellitus, Ht: Hypertension, CVD: Cardiovascular disease, CAD } \\
\text { Coronary artery disease, n: Number }\end{array}$} \\
\hline
\end{tabular}

no doubt that failure of SWL treatment to achieve desired success in lower pole stones has led to use of alternative procedures (5-8).

Flexible ureteroscopy has superiorities such as use of natural orifices, short-stay hospitalization, advantage of concurrent access to all locations of the renal calyceal system, and avoidance of complications resulting from dilatation and adjacent organ injuries in percutaneous interventions. Also, flexible ureteroscopy has low morbidity and the stone free rates similar to that of percutaneous interventions. Metaanalysis studies showed that the stone-free rates of macropercutaneous interventions were still higher than other alternatives, but these procedures have higher complication rate, risk of bleeding and longer hospital stay than, especially, RIRS. Although there are contradictory publications, it has been shown that RIRS, rather than miniaturized percutaneous interventions, may be recommended as a standard treatment in kidney stones smaller than $2 \mathrm{~cm}$ especially in obese patients with high morbidity risk (9).

Extracorporeal shock wave therapy, standard PNL, micro-PNL and RIRS have been performed in our center since 2011. One of the main indications for RIRS is renal and upper ureteral stones of $10-20 \mathrm{~mm}$. Use of ureteral access sheath is not a routine in our center. However, we used flexible ureteroscopy in about 80-90 cases. With careful use, we were able to perform an acceptable number of flexible ureteroscopies without the use of a ureteral access sheath.

In the literature, there are several studies comparing mini-PNL with RIRS, but the stone size was limited to 10-

\begin{tabular}{|c|c|c|c|c|}
\hline Parameters & \multicolumn{2}{|c|}{$\begin{array}{l}\text { Micro-PNL } \\
(\mathrm{n}=23)\end{array}$} & $\begin{array}{l}\text { RIRS } \\
(n=63)\end{array}$ & p \\
\hline Operation time (min) & \multicolumn{2}{|c|}{$54.87 \pm 12.08$} & $55.87 \pm 12.06$ & 0.700 \\
\hline VAS score & \multicolumn{2}{|c|}{$4.48 \pm 1.41$} & $5.02 \pm 6.4$ & 0.752 \\
\hline Need for analgesics & \multicolumn{2}{|c|}{$6(26 \%)$} & $5(7.9 \%)$ & $0.026^{*}$ \\
\hline $\begin{array}{l}\text { Switching to other } \\
\text { treatment or ESWL }\end{array}$ & \multicolumn{2}{|c|}{$2(8.6 \%)$} & $5(9.4 \%)$ & 0.164 \\
\hline \multirow{2}{*}{$\begin{array}{l}\text { Hospitalization time } \\
\text { (day) }\end{array}$} & 1 & $\begin{array}{l}23 \\
(100 \%)\end{array}$ & $61(96.8 \%)$ & \multirow[t]{2}{*}{0.387} \\
\hline & 2 & 0 & $2(3.2 \%)$ & \\
\hline Complication & \multicolumn{2}{|c|}{$4(17.4 \%)$} & $8(12.7 \%)$ & 0.578 \\
\hline Grade 1 & \multicolumn{2}{|l|}{2} & 3 & - \\
\hline Grade 2 & \multicolumn{2}{|l|}{1} & 2 & - \\
\hline Grade 3a & \multicolumn{2}{|l|}{-} & 2 & - \\
\hline Grade 3b & \multicolumn{2}{|l|}{1} & 1 & - \\
\hline Need for retreatment & \multicolumn{2}{|c|}{$0(0)$} & $1(1.8)$ & 0.164 \\
\hline Stone free rate & \multicolumn{2}{|c|}{$18(78.2 \%)$} & $54(85.7 \%)$ & 0.434 \\
\hline
\end{tabular}


$20 \mathrm{~mm}$ in general. In our study, we aimed to compare two procedures in a more specific group of patients. The reasons were lack of comparative studies with micro-PNL and the assumption of lower success rates due to increase in stone diameter and decrease in tract size secondary to deterioration in irrigation and image quality in the micro-PNL technique. In one of the few meta-analysis on this subject, it was emphasized that as stone diameter decreased, stone-free rates increased and micro-PNL and RIRS had comparable stone-free rates. It was also suggested that micro-PNL using a 4.85F "all-seeing" needle was a good alternative to RIRS with favorable stone-free rates and decreased complications related to dilatation. It has been reported that micro-PNL was an alternative to RIRS in patients with a narrow infundibulopelvic angle, stenosis of the calyceal neck and long calyceal neck and in cases where the stone cannot be reached due to deflection angle of the ureteroscope (10). Several factors should be considered when choosing the method in percutaneous procedures: small diameter tools are used for removal of the stone in small fragments which may lead to increased intrapelvic pressure, prolonged fragmentation time, increased metabolic acidosis risk, migration and difficult intrarenal navigation. With regard to flexible ureteroscopy however, problems with the insertion of the accessory sheath, two-stage procedure requirement, ureteral injuries, and problems secondary to J stent placement are presented as the most important factors affecting the method to be chosen. Undoubtedly, the experience of the surgeon is also important (11). Conversion from flexible ureteroscopy to micro-PNL was performed in order to avoid additional anesthesia and procedure requirement and cost effectiveness for the patients. The success rates were reported to be similar in four studies comparing micro-PNL and RIRS methods and it was stated that these two methods were alternative to each other as in our study (9-12). In a prospective randomized study, success rate, analgesic requirement, hemoglobin decrease and pain were similar between patients undergoing RIRS and micro-PNL, however, prolonged fluoroscopy time and hospital stay as well as increased radiation exposure due to "all-seeing needle" were found to be the main disadvantages of micro-PNL (12). In our study, although the stone size decreased partially, we found that there was no significant difference between the two methods in terms of both complication and success rates except the need for analgesic use. Complications rates, hemoglobin drop and length of hospital stay decrease as the diameter of the instrument decreases in percutaneous procedures. We believe that apart from the anatomical factors, the most important parameters in the choice of technique are the technical competence and surgical experience. We believe that the results of our study are meaningful because the operations were performed by the same surgeon with the same tools.

\section{Study Limitations}

The disadvantages of this study include the relatively small number of patients and obtaining the results from a single center and surgeon.

\section{Conclusion}

With the development of minimally invasive therapies, surgical intervention alternatives for kidney stone are increasing. RIRS and micro-PNL may be an alternative treatment for small kidney stones, but it should be noted that there may be perioperative conversions between these two treatment modalities. Although it seems favorable that percutaneous interventions can be performed with a small needle, we should state that it still needs improvement due to image quality and irrigation problems. The availability of RIRS equipment due to the possibility of conversion to RIRS in micro-PNL cases, who do not want SWL, may prevent repeated interventions. In our study, both surgical techniques were similar for all parameters except analgesic requirement, which was higher in the micro-PNL group.

\section{Authorship Contributions}

Concept: Ba.G., B.G. Design: Ba.G., B.G. Data Collection or Processing: Ba.G., B.G. Analysis or Interpretation: Ba.G., B.G. Literature Search: Ba.G., B.G. Writing: Ba.G., B.G.

Conflict of Interest: No conflict of interest was declared by the authors.

Financial Disclosure: The authors declared that this study received no financial support.

\section{References}

1. Türk C, Petřík A, Sarica K, et al. EAU Guidelines on Diagnosis and Conservative Management of Urolithiasis. Eur Urol 2016;69:468-74.

2. Desai J, Solanki R. Ultra-mini percutaneous nephrolithotomy (UMP): one more armamentarium. BJU Int 2013;112:1046-9.

3. Zeng G, Wan S, Zhao Z, et al. Super-mini percutaneous nephrolithotomy (SMP): a new concept in technique and instrumentation. BJU Int 2016;117:655-61.

4. Desai MR, Sharma R, Mishra S, et al. Single-step percutaneous nephrolithotomy (microperc): the initial clinical report. J Urol 2011;186:140-5.

5. Breda A, Ogunyemi O, Leppert JT, Lam JS, Schulam PG, et al. Flexible ureteroscopy and laser lithotripsy for single intrarenal stones $2 \mathrm{~cm}$ or greater-is this the new frontier? J Urol 2008;179:981-4.

6. Monga M, Oglevie S. Minipercutaneous nephorlithotomy. J Endourol 2000;14:419-21. 
7. Desai MR, Sharma R, Mishra S, et al. Singlestep percutaneous nephrolithotomy (microperc): the initial clinical report. J Urol 2011;186:140-5.

8. De S, Autorino R, Kim FJ, et al. Percutaneous Nephrolithotomy Versus Retrograde Intrarenal Surgery: A Systematic Review and Meta-analysis. Eur Urol 2015;67:12137.

9. Gao XS, Liao BH, Chen YT, et al. Different Tract Sizes of Miniaturized Percutaneous Nephrolithotomy Versus Retrograde Intrarenal Surgery: A Systematic Review and Meta-Analysis. J Endourol 2017;31:1101-10.

10. Sabnis RB, Ganesamoni R, Doshi A, et al. Micropercutaneous nephrolithotomy (microperc) vs retrograde intrarenal surgery for the management of small renal calculi: A randomized controlled trial. BJU Int 2013;112:355-61.

11. Ramón de Fata, García-Tello A, Andrés G, et al. Comparative study of retrograde intrarenal surgery and micropercutaneous nephrolithotomy in the treatment of intermediate-sized kidney stones. Actas Urol Esp 2014; 38:576-83.

12. Kandemir A, Guven S, Balasar M, et al. A prospective randomized comparison of micropercutaneous nephrolithotomy (Microperc) and retrograde intrarenal surgery (RIRS) for the management of lower pole kidney Stones. World J Urol 2017;35:1771-76. 